\title{
Efek Rimpang Kunyit (Curcuma longa L.) dan Bawang Putih (Allium sativum L.) terhadap Sensitivitas Insulin pada Tikus Galur Wistar
}

\author{
Evi Sovia, Elin Yulinah Sukandar, Joseph I. Sigit, Lucy Dewi N. Sasongko \\ Sekolah Farmasi ITB
}

\begin{abstract}
Abstrak
Ekstrak kunyit dan bawang putih telah diketahui mempunyai efek antidiabetik, tetapi mekanisme kerjanya belum diketahui. Penelitian ini mengamati efek tiga ekstrak rimpang kunyit (Curcuma longa L.) dan bawang putih (Allium sativum L.), yaitu ekstrak heksan, etil asetat, dan etanol terhadap kadar glukosa darah dengan tes toleransi glukosa. Selanjutnya, ekstrak yang paling efektif dan komponen aktifnya (kurkuminoid dan S-metil sistein) diuji dengan tes toleransi insulin. Empat puluh ekor tikus galur Wistar dibagi menjadi 8 kelompok, yaitu kelompok normal, kelompok yang hanya diberi emulsi tinggi lemak (kontrol), dan sisanya selain diberi emulsi tinggi lemak juga masing-masing diberi ekstrak kunyit dengan dosis $50 \mathrm{mg} / \mathrm{kgBB}$, ekstrak bawang putih dengan dosis $50 \mathrm{mg} / \mathrm{kgBB}$, kurkuminoid dengan dosis $25 \mathrm{mg} / \mathrm{kgBB}$, S-metil sistein dengan dosis $25 \mathrm{mg} / \mathrm{kgBB}$, kombinasi ekstrak kunyitbawang putih dengan dosis masing-masing $25 \mathrm{mg} / \mathrm{kgBB}$, dan kombinasi kurkuminoid-S-metil sistein dengan dosis masing-masing $12,5 \mathrm{mg} / \mathrm{kgBB}$ selama 10 hari. Resistensi insulin dievaluasi dengan tes toleransi insulin. Penelitian dilakukan pada bulan Agustus-Oktober 2010 di Sekolah Ilmu dan Teknologi Hayati (SITH) Institut Teknologi Bandung (ITB). Hasil penelitian ini menunjukkan bahwa $\mathrm{K}_{\text {TTI }}$ (konstanta tes toleransi insulin) hewan kelompok ekstrak bawang putih $(7,2 \pm 0,84)$, kurkuminoid $(7,14 \pm 0,74)$, dan kombinasi kurkuminoid-S-metil sistein $(7,46 \pm 0,64)$ secara bermakna $(\mathrm{p}<0,05)$ lebih besar dibandingkan dengan kelompok kontrol positif $(3,2 \pm 1,92)$. Simpulan, ekstrak bawang putih, kurkuminoid, dan kombinasi kurkuminoid-S-metil sistein meningkatkan sensitivitas insulin. [MKB. 2011;43(4):153-9].
\end{abstract}

Kata kunci: Ekstrak bawang putih, ekstrak kunyit, tes sensitivitas insulin

\section{Effect of Turmeric Extract (Curcuma longa L.) and Garlic Extract (Allium sativum L.) on Insulin Sensitivity}

\begin{abstract}
Studies have shown the antidiabetic effect of turmeric and garlic. However their mechanism of action remain unknown. In this study, we investigated the effect of three turmeric (Curcuma longa L.) and garlic extracts (Allium sativum L.), that are, hexane, ethyl acetate and ethanol extract on blood glucose levels with glucose tolerance test. Furthermore the most effective extracts and its active compound (curcuminoid and S-methyl cysteine) tested with insulin tolerance test. Forty Wistar rats were divided into 8 groups that was normal group, group that treated with a high fat emulsion (control group) and remaining groups were treated with a high fat emulsion and turmeric extract $50 \mathrm{mg} / \mathrm{kgBW}$, garlic extract $50 \mathrm{mg} / \mathrm{kgBW}$, curcuminoid $25 \mathrm{mg} / \mathrm{kgBW}$, S-methyl cysteine $25 \mathrm{mg} / \mathrm{kgBW}$, turmeric-garlic extract combination each $25 \mathrm{mg} / \mathrm{kgBW}$ and curcuminoid-S-methyl cysteine combination each 12,5 $\mathrm{mg} / \mathrm{kgBW}$ for 10 days. Insulin resistance was evaluated by insulin tolerance test. This study conducted from August-October 2010 at Sekolah Ilmu dan Teknologi Hayati (SITH) Institut Teknologi Bandung (ITB). Results of this study showed that insulin tolerance test constanta $\left(\mathrm{K}_{\mathrm{ITT}}\right)$ were bigger in animals that treated with garlic extract (7.2 \pm 0.84$)$, curcuminoid (7.14 \pm 0.74$)$ and combination of curcuminoid-S-methyl cysteine $(7.46 \pm 0.64)$ compared with positive control group (3.2 \pm 1.92$)$. In conclusions garlic extract, curcuminoid and combination of curcuminoid and S-methyl cysteine improve insulin sensitivity. [MKB. 2011;43(4):153-9].
\end{abstract}

Key words: Garlic extract, insulin sensitivity test, turmeric extract

Korespondensi: Evi Sovia, dr., M.Si, Sekolah Farmasi Institut Teknologi Bandung, jalan Ganesa 10 Bandung 40132 , telepon/faks (022) 2504852, mobile08156032199, e-mail soviaevi@yahoo.com 


\section{Pendahuluan}

Diabetes melitus (DM) tipe-2 merupakan gangguan metabolisme yang ditandai dengan resistensi insulin maupun defisiensi insulin relatif atau disfungsi sel $\beta$. Resistensi insulin ditandai dengan peningkatan lipolisis dan produksi asam lemak bebas, peningkatan produksi glukosa hepatik, dan penurunan uptake glukosa otot rangka. Asam lemak bebas secara tidak langsung menyebabkan hiperglikemia dengan merangsang produksi glukosa hepatik. Disfungsi sel $\beta$ terjadi secara progresif dan berperan pada perburukan kontrol gula darah. Pada umumnya penderita mengalami baik resistensi insulin maupun defisiensi insulin. ${ }^{1}$

Peran resistensi insulin dalam patofisiologi DM tipe-2 bukan lagi merupakan sebuah isu. Pada dua dekade terakhir bahkan telah diketahui bahwa implikasi klinis pada defek kerja insulin sangat bervariasi. Resistensi insulin tidak hanya berhubungan dengan DM tipe-2, tetapi juga dengan beberapa penyakit di antaranya penyakit kardiovaskular, hipertensi esensial, sindrom ovarium polikistik, non-alcoholic fatty liver, kanker, sleep apnea, dan gagal jantung kongestif, oleh karena itu obat-obat yang dapatmeningkatkan sensitivitas insulin sangat diperlukan. ${ }^{2}$

Prevalensi DM di seluruh dunia meningkat tajam pada dua dekade terakhir, dari perkiraan 30 juta kasus pada tahun 1985 menjadi 177 juta kasus pada tahun 2000. Berdasarkan tren terbaru $>360$ juta akan menderita DM pada tahun 2030 . Walaupun prevalensi DM tipe 1 dan tipe 2 meningkat di seluruh dunia, prevalensi DM tipe 2 meningkat lebih cepat karena meningkatnya obesitas dan menurunnya aktivitas seperti di negara industri dan 6 dari 10 negara dengan prevalensi tertinggi ada di Asia. Indonesia menduduki urutan ke-4 setelah India, Cina, dan Amerika Serikat. ${ }^{3}$

Jika tidak dikelola dengan baik, DM dapat menyebabkan beberapa komplikasi dan hampir semua dapat terkena, oleh karena itu DM mengakibatkan berbagai keluhan dan memiliki manifestasi klinis yang bervariasi. Pengendalian DM yang baik dapat mencegah keluhan akibat komplikasi yang ada.

Pada saat ini DM ditangani dengan obatobat sintetik yang umumnya lebih mahal dengan efek samping yang relatif lebih tinggi. Indonesia sangat kaya akan bahan obat yang berasal dari alam. Tumbuhan obat tersebut sudah sejak lama dimanfaatkan oleh masyarakat dalam upaya penyembuhan dan pencegahan penyakit. Oleh karena itu, pengembangan obat yang berasal dari bahan alam dapat dimanfaatkan untuk mengatasi kondisi tersebut di atas. Penggunaan obat dari bahan alam diyakini dapat menekan biaya pengobatan yang relatif mahal. Beberapa di antaranya adalah bawang putih (Allium sativum L.) dan kunyit (Curcuma longa L.). Bulbus bawang putih dan rimpang kunyit telah digunakan sebagai obat tradisional untuk menyembuhkan beberapa macam penyakit.

Rimpang kunyit dan komponen aktifnya kurkumin telah diketahui mempunyai efek antidiabetes. ${ }^{4,5}$ Mekanisme kerja kunyit dan kurkumin sebagai antidiabetes diketahui dengan melihat efek ekstrak rimpang kunyit dan kurkumin dalam menstimulasi diferensiasi adiposit dan memperlihatkan aktivitas terhadap peroxisome proliferator-activated receptor gamma (PPAR- $\gamma$ ). ${ }^{5,6}$ Kurkumin juga diketahui menurunkan produksi glukosa di hati dengan mengaktivasi adenosine monophosphate (AMP) kinase dan menginhibisi aktivitas phosphoenolpyruvate carboxykinase (PEPCK). ${ }^{7}$

Bawang putih dari berbagai penelitian terbukti mempunyai efek menurunkan gula darah, kolesterol, dan trigliserida pada tikus yang diinduksi streptozotosin. ${ }^{8-11}$ Beberapa komponen bawang putih, yaitu S-metil sistein sulfoksida dan S-alilsistein sulfoksida juga mempunyai efek antidiabetes. ${ }^{10,11}$ Meskipun mekanisme bulbus bawang putih sebagai antidiabetes belum pasti, tetapi studi in vivo seperti juga studi in vitro memperlihatkan bahwa bulbus bawang putih bekerja sebagai insulin sekretagog pada tikus diabetes. $^{12}$ Studi praklinik maupun studi klinik menunjukkan bahwa kombinasi ekstrak bulbus bawang putih dan rimpang kunyit mempunyai efek hipoglikemik. ${ }^{13,14}$

Penelitian ini bertujuan mengetahui komponen ekstrak yang mempunyai aktivitas antidiabetes, karena itu pembuatan ekstrak dilakukan dengan menggunakan pelarut yang berbeda kepolarannya, yaitu n-heksan, etil asetat, dan etanol. Ketiga ekstrak diuji efek antidiabetesnya dengan tes toleransi glukosa. Selanjutnya, untuk mengetahui efek ekstrak dan komponennya (kurkuminoid dan S-metil sistein) serta kombinasinya terhadap sensitivitas insulin dilakukan tes toleransi insulin terhadap tikus yang diinduksi diet tinggi lemak. Dari penelitian ini diharapkan dapat mengembangkan obat antidiabetes dari herbal yang efektif dan aman.

\section{Metode}

Rimpang kunyit dan bawang putih diperoleh dari Kebun Percobaan Tanaman Obat Manoko, Lembang. Identifikasi dan determinasi tanaman dilakukan di Sekolah Ilmu dan Teknologi Hayati (SITH) Institut Teknologi Bandung (ITB). Kurkuminoid dan S-metil sistein diperoleh dari Sigma Co. USA. 
Rimpang kunyit diiris tipis kemudian dikeringkan dalam lemari pengering dengan suhu $40{ }^{\circ} \mathrm{C}$ selama 1 jam hingga menjadi simplisia kering, sedangkan bulbus bawang putih hanya diiris tipis, tetapi tidak dikeringkan. Sebanyak 1,5 $\mathrm{kg}$ simplisia diekstraksi secara maserasi. Pelarut yang digunakan untuk ekstraksi berdasarkan kepolaran meningkat, yaitu n-heksana, etil asetat, dan etanol 70\%. Maserasi simplisia dilakukan selama 24 jam dengan $3 \mathrm{~L}$ n-heksana, ekstrak disaring dan kemudian dilakukan dua kali maserasi terhadap ampas dengan cara dan pelarut yang sama. Ekstrak sisa ekstraksi dengan n-heksana kemudian dikeringkan. Ampas kering selanjutnya dimaserasi dengan $3 \mathrm{~L}$ etil asetat selama 24 jam, kemudian ekstrak disaring dan terhadap ampas dilakukan dua kali maserasi dengan cara dan pelarut yang sama. Ampas sisa ekstraksi dengan etil asetat dikeringkan dan kemudian dimaserasi dengan $3 \mathrm{~L}$ etanol $70 \%$ selama 24 jam. Ekstrak disaring dan terhadap ampas dilakukan dua kali maserasi dengan cara dan pelarut yang sama. Selanjutnya, ketiga ekstrak: n-heksana, etil asetat, dan etanol $70 \%$ diuapkan dengan alat penguap vakum putar (Buchi Rotavavor R-124, Buchi Waterbath R-480), sehingga diperoleh ekstrak kental. Ekstrak kemudian distandarisasi dengan uji karakterisasi dan penapisan fitokimia. Untuk mengetahui ekstrak yang paling efektif sebagai antidiabetes dilakukan tes toleransi glukosa, selanjutnya ekstrak yang paling efektif diteliti pengaruhnya pada sensitivitas reseptor insulin dengan tes toleransi insulin.

Sebanyak $100 \mathrm{~mL}$ emulsi lemak yang mengandung $20 \mathrm{~g}$ lemak domba, $1 \mathrm{~g}$ propylthiouracil (PTU), $5 \mathrm{~g}$ kolesterol, $1 \mathrm{~g}$ natrium glutamat, $5 \mathrm{~g}$ sukrosa, dan $5 \mathrm{~g}$ sakarosa, $20 \mathrm{~mL}$ tween 80 , dan 30 $\mathrm{mL}$ propilen glikol dilarutkan dalam air distilasi dan disimpan pada suhu $4{ }^{\circ} \mathrm{C} .{ }^{15}$

Penelitian ini menggunakan rancangan eksperimental yang terdiri atas 2 tahap. Pertama, tes toleransi glukosa untuk mengetahui efek antidiabetes masing-masing ekstrak menggunakan 35 ekor tikus. Kedua, tes toleransi insulin untuk mengetahui efek ekstrak dan komponennya terhadap sensitivitas insulin menggunakan 40 ekor tikus yang berbeda dengan tikus yang digunakan untuk tes toleransi glukosa. Skema alur penelitian dapat dilihat pada Gambar.

Hewan yang digunakan sebanyak 35 ekor tikus jantan galur Wistar, berumur 6-8 minggu yang diperoleh dari Laboratorium Hewan Sekolah Farmasi ITB. Hewan diberikan makanan pelet standar dan air minum sesuai kebutuhan serta diadaptasi selama 1 minggu. Hewan ditimbang dan dikelompokkan menjadi 7 kelompok secara acak, masing-masing kelompok terdiri atas 5 ekor tikus. Pada hari pemeriksaan, hewan dipuasakan selama 18 jam, kemudian diukur kadar gula darah puasa (T0) dari vena ekor. Setelah itu, masingmasing hewan diberikan zat uji sesuai dengan kelompoknya. Kelompok 1 diberi ekstrak n-heksan kunyit $50 \mathrm{mg} / \mathrm{kgBB}$, kelompok 2 diberi ekstrak etil asetat kunyit $50 \mathrm{mg} / \mathrm{kgBB}$, kelompok 3 diberi ekstrak etanol kunyit $50 \mathrm{mg} / \mathrm{kgBB}$, kelompok 4 diberi ekstrak n-heksan bawang putih $50 \mathrm{mg} / \mathrm{kgBB}$, kelompok 5 diberi ekstrak etil asetat bawang putih $50 \mathrm{mg} / \mathrm{kgBB}$, kelompok 6 diberi ekstrak etanol bawang putih $50 \mathrm{mg} /$ $\mathrm{kgBB}$, dan kelompok 7 diberi suspensi tragakan (kelompok kontrol). Tiga puluh menit kemudian hewan diberi larutan glukosa standar dengan dosis $3 \mathrm{mg} / \mathrm{kgBB}$ dan diukur kembali kadar gula darahnya. Selanjutnya kadar gula darah diukur setiap 30 menit sampai menit ke-150. ${ }^{16}$

Empat puluh ekor tikus jantan galur Wistar berumur 6-8 minggu yang diperoleh dari Laboratorium Hewan Sekolah Farmasi ITB dibagi menjadi 8 kelompok, yaitu kelompok normal, kelompok yang diberi emulsi tinggi lemak atau kontrol, kelompok yang diberi emulsi tinggi lemak dan ekstrak kunyit dengan dosis 50 $\mathrm{mg} / \mathrm{kgBB}$, kelompok yang diberi emulsi tinggi lemak dan ekstrak bawang putih dengan dosis $50 \mathrm{mg} / \mathrm{kgBB}$, kelompok yang diberi emulsi tinggi lemak dan kurkuminoid dengan dosis 25 $\mathrm{mg} / \mathrm{kgBB}$, kelompok yang diberi emulsi tinggi lemak dan S-metil sistein dengan dosis $25 \mathrm{mg} /$ $\mathrm{kgBB}$, kelompok yang diberi emulsi tinggi lemak dan kombinasi ekstrak kunyit-bawang putih dengan dosis masing-masing $25 \mathrm{mg} / \mathrm{kgBB}$, kelompok yang diberi emulsi tinggi lemak dan kombinasi kurkuminoid-S-metil sistein dengan dosis masing-masing 12,5 mg/kgBB. Perlakuan diberikan selama 10 hari.

Pada hari ke-11, tikus dipuasakan selama 8 jam kemudian ditimbang. Glukosa darah diperiksa setiap 30 menit sebanyak lima kali setelah pemberian insulin secara intraperitoneal $(0,05 \mathrm{U} / \mathrm{kgBB})$ menggunakan glukosameter (Life scan, One Touch Ultra, Melitas, CA). Aksis menunjukkan waktu dan ordinat menunjukkan kadar gula darah. Koefisien regresi (r) atau slope ditentukan dengan regresi linier dan konstanta tes toleransi insulin $\left(\mathrm{K}_{\mathrm{TT}}\right)$ dihitung dengan mengalikan $r$ dengan 100. Nilai $\mathrm{K}_{\mathrm{TTI}}$ menunjukkan sensitivitas insulin dan nilai $\mathrm{K}$ yang lebih rendah menunjukkan sensitivitas yang rendah. ${ }^{14}$

Penelitian ini dilakukan pada bulan Agustus sampai dengan bulan Oktober 2010.

Untuk menentukan jumlah sampel tiap kelompok didasarkan pada rumus Fereder, yaitu: $(\mathrm{r}-1)(\mathrm{t}-1) \geq 15$ (keterangan: $\mathrm{r}=\mathrm{jumlah}$ sampel, $\mathrm{t}=$ jumlah perlakuan). Pada penelitian ini terdapat 7 kelompok perlakuan untuk tes toleransi glukosa (TTG) dan 8 kelompok perlakuan untuk 


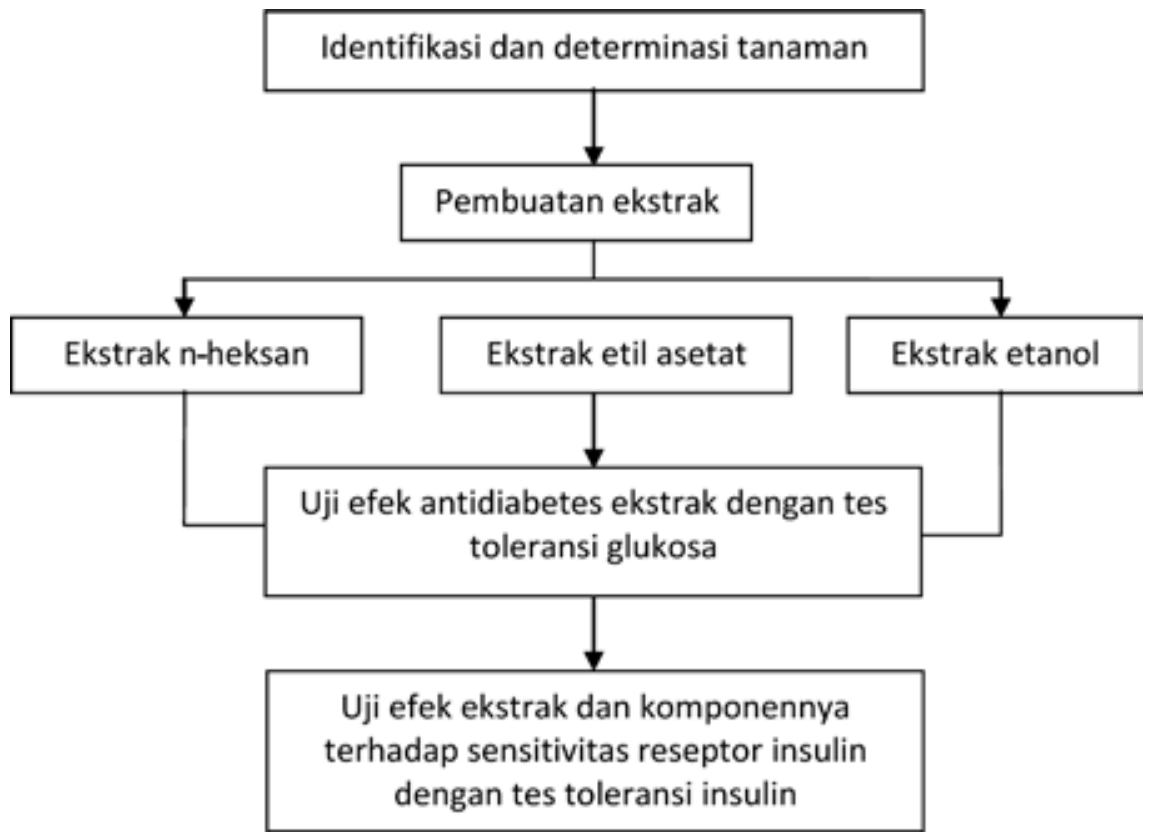

Gambar Skema Alur Penelitian

tes toleransi insulin (TTI), maka hewan yang dibutuhkan minimal 3 ekor per kelompok.

Data yang diperoleh dianalisis menggunakan student t-test untuk membandingkan kelompok perlakuan dengan kelompok kontrol.

\section{Hasil}

Hasil uji karakterisasi dan penapisan fitokimia ekstrak dapat dilihat pada Tabel 1 dan 2. Hasil tes toleransi glukosa menunjukkan glukosa darah puasa (T0) semua kelompok masih sedikit di atas normal kecuali kelompok ekstrak etil asetat bawang putih dan ekstrak etanol bawang putih dalam batas normal $(<100 \mathrm{mg} / \mathrm{dL})$. Setelah pemberian glukosa (T60), kadar glukosa darah mengalami kenaikan pada semua kelompok, tetapi kelompok yang diberi ekstrak kenaikannya lebih kecil. Kadar glukosa darah setelah 30 menit pemberian glukosa (T90) mengalami penurunan pada semua kelompok dengan pengukuran setiap 30 menit kecuali pada kelompok kontrol mengalami peningkatan pada menit ke-120. Pada menit ke-150, kadar glukosa darah semua kelompok perlakuan kembali normal kecuali kelompok kontrol (Tabel 3).

Semua ekstrak memperlihatkan penurunan kadar gula darah, tetapi yang bermakna hanya ekstrak etil asetat $(p<0,05)$. Hal ini menunjukkan bahwa ekstrak etil asetat mempunyai efek hipoglikemia paling baik. Untuk penelitian selanjutnya yang digunakan adalah ekstrak etil asetat. Penelitian dilanjutkan dengan mengamati pengaruh ekstrak etil asetat kunyit, ekstrak etil asetat bawang putih, kurkuminoid, S-metil sistein, kombinasi ekstrak etil asetat kunyitbawang putih, serta kombinasi kurkuminoidS-metil sistein pada peningkatan sensitivitas reseptor insulin.

Hasil tes toleransi insulin dari pengukuran glukosa darah kapiler memperlihatkan penurunan

Tabel 1 Hasil Karakterisasi Ekstrak Etil Asetat Kunyit dan Bawang Putih

\begin{tabular}{lcc}
\hline \multirow{2}{*}{ Kadar } & & Hasil (\%) \\
\cline { 2 - 3 } & Kunyit & Bawang Putih \\
\hline Air & 3,20 & 4,50 \\
Abu total & 2,90 & 3,17 \\
Abu tidak larut asam & 1,07 & 1,88 \\
Abu tidak larut air & 0,47 & 0,03 \\
Sari larut etanol & 9,10 & 16,8 \\
Sari larut air & 5,85 & 10,0 \\
\hline
\end{tabular}


Tabel 2 Hasil Penapisan Fitokimia Ekstrak Etil Asetat Kunyit dan Bawang Putih

\begin{tabular}{ccc}
\hline Parameter & Kunyit & Bawang Putih \\
\hline Alkaloid & + & + \\
Flavanoid & - & - \\
Tanin & - & - \\
Kuinon & + & - \\
Saponin & - & + \\
Steroid/triterpenoid & + & + \\
\hline
\end{tabular}

+ : terdeteksi dalam ekstrak, - : tidak terdeteksi dalam ekstrak

$\mathrm{K}_{\mathrm{TI}}$ yang sangat bermakna $(\mathrm{p}=0,001)$ pada kelompok kontrol yang diberi emulsi tinggi lemak secara per oral selama 10 hari $(3,2 \pm 2,07)$ dibandingkan dengan kelompok normal yang tidak diberi emulsi tinggi lemak $(7,86 \pm 0,95)$. Hal ini menunjukkan bahwa pemberian emulsi tinggi lemak menyebabkan menurunnya sensitivitas reseptor insulin.

Konstanta tes toleransi insulin kelompok ekstrak bawang putih $(7,2 \pm 0,84)$, kurkuminoid $(7,14 \pm 0,74)$, dan kombinasi kurkuminoid-S-metil sistein $(7,46 \pm 0,64)$ meningkat secara bermakna $(p<0,05)$ dibandingkan dengan kelompok kontrol $(3,2 \pm 1,92)$, sedangkan peningkatan $\mathrm{K}_{\mathrm{T}}$ pada kelompok ekstrak kunyit $(3,4 \pm 2,07)$, S-metil sistein $(4,32 \pm 1,68)$, dan kelompok kombinasi kunyit bawang putih $(4,6 \pm 0,55)$ tidak bermakna (Tabel 4).

\section{Pembahasan}

Pada penelitian ini diamati kemampuan ekstrak n-heksan, ekstrak etil asetat, serta ekstrak etanol kunyit dan bawah putih dalam menurunkan kadar glukosa darah dengan menggunakan tes toleransi glukosa oral (TTGO). Hasil penelitian menunjukkan bahwa pada semua ekstrak terdapat penurunan kadar glukosa darah setelah pembebanan glukosa sebanyak $3 \mathrm{mg} / \mathrm{kgBB}$, tetapi menunjukkan penurunan yang bermakna ekstrak etil asetat.

Penelitian ini memperlihatkan hasil yang berbeda dengan penelitian sebelumnya karena pada penelitian ini dibandingkan kemampuan tiga ekstrak (n-heksan, etil asetat, dan etanol) kunyit dan bawang putih. Penelitian sebelumnya hanya menggunakan satu jenis ekstrak, yaitu etanol kunyit serta ekstrak air bawang putih dan menunjukkan efek hipoglikemia pada kedua ekstrak tersebut. ${ }^{13}$ Hal ini kemungkinan disebabkan pembuatan ekstrak pada penelitian ini berbeda dengan penelitian sebelumnya. Pada penelitian ini, pembuatan ekstrak dilakukan dengan ekstraksi bertingkat menggunakan pelarut yang berbeda kepolarannya, yaitu n-heksan, etil asetat dan etanol, sedangkan pada penelitian sebelumnya hanya menggunakan satu pelarut, yaitu etanol untuk kunyit dan air untuk bawang

Tabel 3 Kadar Glukosa Darah Selama Uji Toleransi Glukosa

\begin{tabular}{llllllll}
\hline \multirow{2}{*}{$\begin{array}{c}\text { Waktu } \\
\text { (menit) }\end{array}$} & $\begin{array}{c}\text { Ekstrak } \\
\text { n-heksan } \\
\text { Kunyit }\end{array}$ & $\begin{array}{c}\text { Ekstrak } \\
\text { Etil Asetat } \\
\text { Kunyit }\end{array}$ & $\begin{array}{c}\text { Ekstrak } \\
\text { Etanol } \\
\text { Kunyit }\end{array}$ & $\begin{array}{c}\text { Ekstrak } \\
\text { n-heksan } \\
\text { Bawang } \\
\text { Putih }\end{array}$ & $\begin{array}{c}\text { Ekstrak } \\
\text { Etil Asetat } \\
\text { Bawang } \\
\text { Putih }\end{array}$ & $\begin{array}{c}\text { Ekstrak } \\
\text { Etanol } \\
\text { Bawang } \\
\text { Putih }\end{array}$ & Kontrol \\
\hline \multirow{2}{*}{ T0 } & 107,25 & 102,33 & 109,67 & 103,33 & 95 & 90,33 & 109,33 \\
& $\pm 11,24$ & $\pm 6,03^{*}$ & $\pm 4,16$ & $\pm 11,15$ & $\pm 20,66^{*}$ & $\pm 5,50$ & $\pm 12,90$ \\
T30 & 108,50 & 102,33 & 109,67 & 100,5 & 90,8 & 96,33 & 110 \\
& $\pm 16,60$ & $\pm 2,88^{*}$ & $\pm 4,16$ & $\pm 51,11$ & $\pm 10,69^{*}$ & $\pm 43,25$ & $\pm 16,64$ \\
T60 & 149,75 & 140,33 & 147,67 & 140 & 145 & 140,33 & 155,33 \\
& $\pm 36,38$ & $\pm 14,57^{*}$ & $\pm 9,02$ & $\pm 10,00$ & $\pm 10,00^{*}$ & $\pm 22,37$ & $\pm 24,54$ \\
T90 & 108,50 & 125,33 & 135,67 & 100,33 & 76,33 & 116,33 & 156 \\
& $\pm 12,82$ & $\pm 13,43^{*}$ & $\pm 17,62$ & $\pm 4,04$ & $\pm 10,01^{*}$ & $\pm 23,46$ & $\pm 14,73$ \\
T120 & 118,75 & 101 & 136,67 & 98 & 77 & 120,67 & 132,67 \\
& $\pm 23,37$ & $\pm 16,37^{*}$ & $\pm 14,22$ & $\pm 19,16$ & $\pm 9,54^{*}$ & $\pm 11,02$ & $\pm 11,02$ \\
$\mathrm{~T} 150$ & 98,75 & 71,67 & 106,33 & 90,33 & 67,33 & 118,67 & 124 \\
& $\pm 38,80$ & $\pm 12,22^{*}$ & $\pm 8,33$ & $\pm 42,03$ & $\pm 13,28^{*}$ & $\pm 16,62$ & $\pm 5,30$ \\
\hline
\end{tabular}

*p<0,05 dibandingkan dengan kontrol, menggunakan uji t 
Tabel 4 Hasil Pengukuran $\mathrm{K}_{\mathrm{TTI}}$ Semua Kelompok Setelah Dilakukan Tes Toleransi Insulin

\begin{tabular}{cc}
\hline Kelompok & $\mathbf{K}_{\mathrm{TTI}}$ \\
\hline Ekstrak kunyit & $3,4 \pm 2,07$ \\
Ekstrak bawang putih & $7,2 \pm 0,84^{*}$ \\
Kurkuminoid & $7,1 \pm 0,74^{*}$ \\
S-metil sistein & $4,3 \pm 1,68$ \\
Kombinasi ekstrak kunyit-bawang putih & $4,6 \pm 0,55$ \\
Kombinasi kurkuminoid- S-metil sistein & $7,5 \pm 0,64^{*}$ \\
Kontrol & $3,2 \pm 1,92$ \\
Normal & $7,9 \pm 0,95$ \\
\hline
\end{tabular}

Keterangan: $\mathrm{K}_{\mathrm{ITT}}$ : konstanta tes toleransi insulin; ${ }^{*} \mathrm{p}<0,05$ dibandingkan dengan kontrol

putih; karena itu kemungkinan senyawa yang terkandung dalam setiap ekstrak akan berbeda, sehingga mempengaruhi aktivitasnya sebagai antidiabetes.

Penelitian sebelumnya memperlihatkan bahwa ekstraksi dengan etanol akan menghasilkan kurkuminoid dan seskuiterpenoid, sedangkan ekstraksi dengan n-heksan akan menghasilkan seskuiterpenoid. Ekstraksi dengan etil asetat belum diteliti senyawa yang dihasilkannya, tetapi kemungkinan konsentrasi kurkuminoid dalam ekstrak etil asetat lebih tinggi karena kurkuminoid bersifat semipolar. ${ }^{6}$

Penelitian ini dilakukan sebagai penelitian pendahuluan untuk mengetahui ekstrak yang paling efektif. Penelitian ini menunjukkan bahwa ekstrak etil asetat paling efektif sebagai antidiabetes, sehingga penelitian selanjutnya menggunakan ekstrak etil asetat. Untuk mengamati pengaruh ekstrak dan senyawa aktifnya pada sensitivitas reseptor insulin digunakan model hewan yang resisten terhadap insulin dengan pemberian emulsi tinggi lemak.

Hasil tes toleransi insulin menggunakan glukosa darah kapiler memperlihatkan penurunan $\mathrm{K}_{\mathrm{TTI}}$ yang bermakna $(p=0,001)$ pada kelompok kontrol yang diberi emulsi tinggi lemak secara per oral selama 10 hari dibandingkan dengan kelompok normal. Hal ini menunjukkan bahwa pemberian emulsi tinggi lemak menurunkan sensitivitas reseptor insulin. Hasil penelitian ini mendukung penelitian sebelumnya yang menunjukkan bahwa pemberian emulsi tinggi lemak menurunkan sensitivitas insulin yang ditandai dengan menurunnya $\mathrm{K}_{\mathrm{TTI}} 15$

Konstanta tes toleransi insulin kelompok ekstrak bawang putih, kurkuminoid, serta kombinasi kurkuminoid, dan S-metil sistein meningkat secara bermakna $(\mathrm{p}<0,05)$ dibandingkan dengan kelompok kontrol. Hal ini menunjukkan bahwa pemberian ekstrak bawang putih, kurkuminoid, dan kombinasi kurkuminoid-S-metil sistein dapat meningkatkan sensitivitas reseptor insulin. Hasil penelitian ini mendukung penelitian sebelumnya menyatakan bahwa kurkumin menstimulasi diferensiasi adiposit dan memperlihatkan aktivitas terhadap PPAR- $\gamma$ yang berperan untuk meningkatkan sensitivitas reseptor insulin. Hal ini juga menunjukkan kemungkinan mekanismenya sebagai antidiabetes. ${ }^{5-7}$ Demikian juga ketika dikombinasi dengan S-metil sistein, kurkuminoid masih memperlihatkan efeknya untuk meningkatkan sensitivitas insulin, $\mathrm{K}_{\mathrm{TTI}}$ kombinasi kurkuminoid-S-metil sistein lebih besar $(7,46 \pm 0,64)$ dibandingkan dengan $\mathrm{K}_{\mathrm{TTI}}$ kurkuminoid $(7,14 \pm 0,74)$ tetapi tidak bermakna.

Studi in vivo dan in vitro memperlihatkan bahwa bulbus bawang putih bekerja sebagai insulin sekretagog pada tikus diabetes melitus. ${ }^{12}$ Penelitian ini menunjukkan bahwa bawang putih dapat meningkatkan sensitivitas reseptor insulin yang kemungkinan berperan juga dalam aktivitasnya sebagai antidiabetes. $\mathrm{K}_{\mathrm{TTI}}$ kelompok ekstrak kunyit, S-metil sistein, dan kombinasi ekstrak kunyit-bawang putih tidak berbeda dengan kelompok kontrol. Hal ini menunjukkan bahwa ekstrak kunyit, S-metil sistein, dan kombinasi ekstrak kunyit-bawang putih tidak dapat meningkatkan sensitivitas reseptor insulin.

Kurkuminoid sebagai komponen utama ekstrak kunyit dapat meningkatkan sensitivitas reseptor insulin, tetapi ekstrak kunyit tidak mempunyai aktivitas tersebut. Hal ini kemungkinan karena kandungan kurkuminoid dalam ekstrak kunyit hanya 3-4\%. ${ }^{17}$ Ekstrak bawang putih memperlihatkan aktivitas meningkatkan sensitivitas reseptor insulin, tetapi ketika dikombinasikan dengan ekstrak kunyit aktivitasnya menurun. Hal ini kemungkinan disebabkan ekstrak kunyit menghambat aktivitas ekstrak bawang putih terhadap peningkatan sensitivitas reseptor insulin. Penelitian sebelumnya pada hewan percobaan dan uji klinik menunjukkan efek sinergis ekstrak kunyit dan ekstrak bawang putih sebagai antidiabetes. ${ }^{13,17}$ Kemungkinan kombinasi ekstrak kunyit dan bawang putih bekerja secara sinergis pada jalur mekanisme kerja yang 
lain dari antidiabetes.

S-metil sistein merupakan salah satu komponen bawang putih. S-metil sistein diketahui mempunyai aktivitas antidiabetes, tetapi mekanisme kerjanya sebagai antidiabetes belum diketahui. ${ }^{10,11}$ Pada penelitian ini S-metil sistein secara tunggal tidak menunjukkan aktivitas peningkatan sensitivitas reseptor insulin, tetapi ketika dikombinasikan dengan kurkuminoid aktivitasnya lebih besar dibandingkan dengan pemberian kurkuminoid secara tunggal.

Kesimpulan penelitian ini, bahwa ekstrak bawang putih, kurkuminoid, dan kombinasi kurkuminoidS-metil sistein meningkatkan sensitivitas reseptor insulin. Implikasi penelitian ini, kunyit dan bawang putih maupun komponennya yaitu kurkuminoid dan S-metil sistein dapat dikembangkan sebagai obat antidiabetes.

\section{Daftar Pustaka}

1. Oki JC, Isley WI. Diabetes mellitus. Dalam: Di Piro JT, Talbert RL, penyunting. Pharmacotherapy, patophysiologic approach. Edisi ke-5. New York: McGraw Hill; 2002. hlm. 1335-41.

2. Reaven GM. The insulin resistance síndrome: concept and therapeutic approaches. Dalam: Mongensen CE, penyunting. Pharmacotherapy of diabetes: new development. Denmark: Springer; 2007. hlm. 19-27.

3. Powers AC. Diabetes mellitus. Dalam: Fauci AS, Braunwald E, Kasper DL, Hauser SL, Longo DL, Jameson JL, penyunting. Harrison's principles of internal medicine. Chicago: McGraw Hill; 2008. hlm. 2275304.

4. Hussain HEM. Hypoglycemic, hypolipidemic and antioxidant properties of combination of curcumin from curcuma longa, linn, and partially purified product from abroma augusta, linn. in streptozotocin induced diabetes. Indian $\mathrm{J}$ Clin Biochem. 2002;17:33-43.

5. Kuroda M, Mimaki Y, Nishiyama $T$, Mae T, Kishida H, Tsukagawa M, dkk. Hypoglycemic effects of turmeric (Curcuma longa L. rhizomes) on genetically diabetic KK-Ay mice. Biol Pharm Bull. 2005; 28:937-9.

6. Nishiyama T, Mae T, Kishida H, Tsukagawa M, Mimaki Y, Kuroda M, dkk. Curcuminoids and sesquiterpenoids in turmeric (Curcuma longa L) suppress and increase in blood glucose level in type 2 diabetic KK-Ay mice. J Agric Food Chem. 2005;53:959-63.

7. Fujiwara H, Hosokawa M, Zhou X, Fujimoto S, Fukuda K, Toyoda K, dkk. Curcumin inhibits glucose production in isolated mice hepatocytes. Diabetes Res Clin Pract. 2008;80:185-91.

8. Thomson M, Al-Amin ZM, Al-Qattan KK, Shaban LH, Ali M. Anti-diabetic and hypolipidaemic properties of garlic (Allium sativum) in streptozotocin-induced diabetic rats. Intern J Diabetes Metab. 2007;15:10815.

9. Eidi A, Eidi M, Esmaelia E. Antidiabetic effect of garlic (Allium sativum L.) in normal and streptozotocin-induced diabetic rats. Phytomed. 2006;13:624-9.

10. Sheela CG, Kumud K, Augusti KT. Antidiabetic effects of onion and garlic sulfoxide amino acids in rats. Planta Med. 1995;61: $356-7$.

11. Sheela CG, Augusti KT. Antidiabetic effects of S-allyl cysteine sulphoxide isolated from garlic Allium sativum Linn. Indian J Exp Biol. 1992;30(6):523-6.

12. Banarjee SK, Maulik SK. Effect of garlic on cardiovascular disorders: a review. J Nutr. 2002;1:4 doi:10.1186/1475-2891-1-4.

13. Sukandar EY, Sigit JI, Deviana R. Antihyperlipidemic and antidiabetic effect of combination of garlic and turmeric extract in rats. J Medika Planta. 2011;1:2-8.

14. Sukandar EY, Permana H, Adnyana IK, Sigit JI, Hasimun P, Mardiyah D. Clinical study of turmeric (curcuma longa L.) and garlic (allium sativum L.) extract as antihyperglicemic and antihyperlipidemic agent in type-2 diabetes dyslipidemia patients. Int $\mathbf{J}$ Pharmachol. 2010;6(4):456-63.

15. Ai J, Wang N, Yang M, Min Du Z, Zhang YC, Yang BF. Development of wistar rat model of insulin resistance. World J Gastroenterol. 2005;11(24):3675-9.

16. Kelompok Kerja Ilmiah. Penapisan farmakologi, pengujian fitokimia dan pengujian klinik. Jakarta: Yayasan Pengembangan Obat Bahan Alam Phyto Medica; 1993.

17. Ishita C, Biswas $\mathrm{K}$, Bandyopadhyay $\mathrm{U}$, Banerjee RK. Turmeric and curcumin: biological actions and medical applications. Curr Sci. 2004;87:44-53. 